See discussions, stats, and author profiles for this publication at: https://www.researchgate.net/publication/331928669

\title{
Evidence for different thermal ecotypes in range centre and trailing edge kelp populations
}

Article in Journal of Experimental Marine Biology and Ecology · March 2019

Dol: 10.1016/j.jembe.2019.03.004

\section{CITATIONS}

20

8 authors, including:

Nathan G King

Bangor University

14 PUBLICATIONS 179 CITATIONS

SEE PROFILE

4. Dan A Smale

Marine Biological Association of the UK

123 PUBLICATIONS 7,625 CITATIONS

SEE PROFILE

Some of the authors of this publication are also working on these related projects:

Project Phylogeography of the Azores View project

Project

EU BlueFish View project
467

Niall J. Mckeown

Aberystwyth University

91 PUBLICATIONS 578 CITATIONS

SEE PROFILE

David C. Wilcockson

Aberystwyth University

67 PUBLICATIONS 1,936 CITATIONS

SEE PROFILE 


\title{
Evidence for different thermal ecotypes in range centre and trailing edge kelp populations
}

\author{
Nathan G. King ${ }^{\mathrm{a}, \mathrm{b}, *}$, Niall J. McKeown ${ }^{\mathrm{b}}$, Dan A. Smale ${ }^{\mathrm{c}}$, David C. Wilcockson ${ }^{\mathrm{b}}$, Laura Hoelters ${ }^{\mathrm{b}}$, \\ Emily A. Groves ${ }^{\mathrm{a}}$, Thomas Stamp ${ }^{\mathrm{d}}$, Pippa J. Moore ${ }^{\mathrm{b}, \mathrm{e}}$ \\ ${ }^{a}$ Centre of Applied Marine Science, Bangor University, Menai Bridge LL59 5AB, UK \\ ${ }^{\mathrm{b}}$ Institute of Biological, Environmental and Rural Sciences, Aberystwyth University, Aberystwyth SY23 3DA, UK \\ ${ }^{\mathrm{c}}$ Marine Biological Association of the United Kingdom, The Laboratory, Citadel Hill, Plymouth PL1 2PB, UK \\ ${ }^{\mathrm{d}}$ School of Biological and Marine Sciences, Plymouth University, PL4 8AA, UK \\ ${ }^{\mathrm{e}}$ Centre of Marine Ecosystems Research, School of Natural Sciences, Edith Cowan University, Joondalup 6027, Western Australia, Australia
}

A R T I C L E I N F O

\section{Keywords:}

Laminaria digitata

Range-centre

Trailing-edge

Climate change

Heat shock

\begin{abstract}
A B S T R A C T
Determining and predicting species' responses to climate change is a fundamental goal of contemporary ecology. When interpreting responses to warming species are often treated as a single physiological unit with a single species-wide thermal niche. This assumes that trailing edge populations are most vulnerable to warming, as it is here where a species' thermal niche will be exceeded first. Local adaptation can, however, result in narrower thermal tolerance limits for local populations, so that similar relative increases in temperature can exceed local niches throughout a species range. We used a combination of common garden temperature heat-shock experiments $\left(8-32^{\circ} \mathrm{C}\right.$ ) and population genetics (microsatellites) to identify thermal ecotypes of northeast Atlantic range centre and trailing edge populations of the habitat-forming kelp, Laminaria digitata. Using upregulation of hsp70 as an indicator of thermal stress, we found that trailing edge populations were better equipped to tolerate acute temperature shocks. This pattern was consistent across seasons, indicating that between-population variability is fixed. High genetic structuring was also observed, with range centre and trailing edge populations representing highly distinct clusters with little gene flow between regions. Taken together, this suggests the presence of distinct thermal ecotypes for L. digitata, which may mean responses to future warming are more complex than linear range contractions.
\end{abstract}

\section{Introduction}

Temperature is one of the most important drivers of ecological patterns and processes (Hutchins, 1947), dictating where a species can exist and how well it performs throughout its distribution (Brown, 1984; Dunson and Travis, 1991; Gaston, 2003). Rising global temperatures, from anthropogenic greenhouse gas emissions, have already resulted in the altered performance and poleward range migrations of a range of biota and is set to continue as climate change advances (Walther et al., 2002; Parmesan and Yohe, 2003; Burrows et al., 2011; Sunday et al., 2012; Poloczanska et al., 2013). As range migrations and altered performances can have serious implications for the structure and functioning of entire ecosystems (Walther et al., 2002, Parmesan, 2006, Doney et al., 2011), understanding the effect of rising temperatures on species performance and distributions is a key goal in climate change ecology. However, if this is to be achieved then we must first understand the physiological traits and mechanisms that govern existing species distributions.

When forecasting future distributions, species are often treated as a single homogenous unit (Pearman et al., 2010; Reed et al., 2011), with populations assumed to exhibit similar thermal limits throughout the species' range. Therefore, thermal safety margins, the buffer between experienced temperatures and a species upper thermal limits (see Deutsch et al., 2008; Bennett et al., 2015), are assumed greatest at the range centre and lowest at trailing edges. As such, range centre populations are generally considered to be less vulnerable to predicted warming trends than trailing edge populations, where thermal safety margins will be exceeded first (Thomas et al., 2006; Thomas, 2010). Along temperature gradients, however, thermal tolerances are not always consistent between populations, as local adaptation and/or phenotypic plasticity can result in thermal limits being different across a species biogeographic range (Sanford and Kelly, 2011). This may result

\footnotetext{
* Corresponding author at: Centre of Applied Marine Science, Bangor University, Menai Bridge LL59 5AB, UK.

E-mail address: n.king@bangor.ac.uk (N.G. King).
} 
in more complex responses to warming than simple linear range contractions from trailing edges (Sanford and Kelly, 2011; Valladares et al., 2014; Bennett et al., 2015; Pontes-da-Silva et al., 2018), meaning central populations may also be vulnerable to ongoing warming.

Within the context of decadal scale warming, the significance of intraspecific variation in thermal niche largely depends on the mechanisms responsible (i.e. plasticity vs. adaptation). If the response is plastic then species are likely to be able to keep pace with climate warming, but if responses are a result of adaptation then the pace of warming is likely to be too fast for natural selection (Jump and Penuelas, 2005; Quintero and Wiens, 2013). Gaining an understanding of gene flow can provide valuable insight into whether adaptation or plasticity is favoured. Where gene flow is greater than the selection gradient, there is likely to be little selection for local thermal adaptation, resulting in a single plastic phenotype (García-Ramos and Kirkpatrick, 1997; Kirkpatrick and Barton, 1997), whereas restricted gene flow facilitates the development of local ecotypes (Endler, 1977).

Sessile organisms, that cannot modify their behaviour, rely on physiological mechanisms, underpinned by modulation of gene expression, to mediate periods of thermal stress. Whilst the mechanisms themselves are evolutionary conserved, patterns in gene expression are heritable and can vary considerably between populations (López-Maury et al., 2008) resulting in population level differences in thermal tolerance (e.g. Henkel and Hofmann, 2008). Therefore, analysis of variation in gene expression offers a powerful tool to identify thermal set points of a population that are often apparent before higher level physiological differences are observed. The Heat Shock Response (HSR) is perhaps the most well studied mechanism for identifying differences in thermal physiology. When organisms are challenged by elevated temperatures that result in protein denaturation and aggregation they rapidly upregulate a suite of molecular chaperones known as heat shock proteins (HSPs). These HSPs preserve normal cell function by ensuring appropriate protein folding during translation (Frydman, 2001), membrane stability and transport (Hartl and Hayer-Hartl, 2002) and protein refolding (Hendrick and Hartl, 1993).

Kelps are large brown habitat-forming seaweeds that form extensive forests along rocky coastlines in temperate and subpolar regions (Steneck et al., 2002; Smale et al., 2013; Teagle et al., 2017). Kelp forests rank among the world's most productive and extensive habitats, being distributed along one-quarter of the world's coastlines and rivalling the productivity of tropical rainforests (Leith and Whittaker, 1975; Mann, 1973). Kelp exist over vast temperature gradients and whilst long distance dispersal is possible (e.g. Fraser et al., 2018) the majority of spores settle within a few meters of the parent alga (e.g. Norton, 1992; Kendrick and Walker, 1995). Therefore, local adaptation may be a common feature throughout kelp distributions. Given that climate mediated range shifts have already been observed in kelp forests across the world (Marba and Duarte, 2010; Wernberg et al., 2016; Krumhansl et al., 2016) and are predicted to continue as warming progresses (e.g. Martínez et al., 2012; Jueterbock et al., 2013; Khan et al., 2018; Assis et al., 2018) understanding whether intraspecific variation in thermal niche may make central populations vulnerable to future warming trends has direct relevance for management and conservation of kelp forest ecosystems.

In this study we investigated intraspecific variation in the Heat Shock Response (HSR) of Laminaria digitata (Hudson) J.V. Lamouroux, a common transatlantic kelp. Specifically, we compared populations from two thermally distinct regions in the United Kingdom (representing East Atlantic range centre and trailing edge populations) and conducted experiments at the coolest and warmest times of year, to characterise intraspecific and intra-annual variability in HSRs. We also used neutral microsatellite markers to gain an understanding of gene flow between populations. By adopting a multi-pronged experimental approach we aimed to determine (i) whether populations show differentiation in thermal niche and (ii) whether such differences are likely a product of plasticity or adaptation.

\section{Methods}

\subsection{Study species}

L. digitata is an important ecosystem engineer that forms highly productive stands supporting rich associated communities (Schultze et al., 1990). It has a transatlantic-boreal distribution stretching from the Arctic, where sea ice cover, light availability and low temperatures limit its leading edge, to the English Channel in the East Atlantic and Cape Cod along the US Eastern Seaboard, where it is limited by high summer temperatures. Currently, no climate related population declines have been observed in the West Atlantic (Merzouk and Johnson, 2011) but declines in abundance have been reported in the East Atlantic, although disentangling the roles of overexploitation and warming is difficult (Cosson, 1999; Simkanin et al., 2005; Gevaert et al., 2008). However, as climate change advances, population losses are predicted at both $L$. digitata's East and West Atlantic trailing edges (Raybaud et al., 2013; Khan et al., 2018). In the West Atlantic a lack of subtidal competition means $L$. digitata can extend well into the subtidal ( $>20 \mathrm{~m}$ ) but in the East Atlantic the presence of the subtidal congener L. hyperborea restricts $L$. digitata to the low intertidal/shallow subtidal. This means that East Atlantic populations will not be able to move to deeper locations as temperatures in the intertidal become inhospitable. However, the narrow linear distribution of L. digitata's East Atlantic range make it ideally suited to understanding how temperature facilitates the development of thermal ecotypes as it is unconfounded by covarying factors associated with depth.

\subsection{Heat shock experiment}

\subsubsection{Patterns of the heat shock response}

One of the most highly conserved and well-studied group of HSPs is the Hsp70 family. By measuring the thermal profile of hsp70 upregulation (temperature at which HSPs are synthesised, $\mathrm{T}_{\text {on }}$, maximally expressed, $\mathrm{T}_{\text {peak }}$, and turned off, $\mathrm{T}_{\text {off }}$ ) it is possible to investigate intra and inter specific differences in thermal tolerance (Tomanek and Somero, 1999; Barua and Heckathorn, 2004; Tomanek, 2010). $\mathrm{T}_{\text {on }}$ represents the minimum temperature to cause stress, $\mathrm{T}_{\text {peak }}$ the upper thermal limit of tolerance beyond which protein synthesis can no longer meet the cellular response demands and $\mathrm{T}_{\text {off }}$ the likely ultimate upper limit in the functioning of the translational machinery (Barua and Heckathorn, 2004; Tomanek, 2010). By comparing these profiles between populations at different latitudes within a species' biogeographic range, it is possible to quantify intraspecific variation in thermal tolerances and to begin to predict how populations, and species, may respond to continued warming.

\subsubsection{Survey periods and sites}

We sampled Laminaria digitata populations by employing a nested hierarchical design. Two regions were selected to represent range centre and trailing edge populations (Fig. 1); Within each region two sampling sites were randomly selected; Warbeth, northern Scotland (hereafter 'range centre 1'), Easdale western Scotland (hereafter 'range centre 2'), Trevone, southwest England (hereafter 'trailing edge 1') and St Mawes, southwest England (hereafter 'trailing edge 2'). These regions are thermally distinct with a mean temperature difference of $\sim$ $2.5^{\circ} \mathrm{C}$ in winter and $\sim 4{ }^{\circ} \mathrm{C}$ in summer (Smale and Moore, 2017; Pessarrodona et al., 2018). Although the absolute range edge of $L$. digitata extends to Brittany, $\left(\sim 48^{\circ} \mathrm{N}\right)$, the temperature regimes either side of the English Channel are similar (mean September SST near St Mawes - 'trailing edge $2=17{ }^{\circ} \mathrm{C}$, mean SST in southern Brittany, France $=$ $17.4^{\circ} \mathrm{C}$ ), and as such, the southwest England sites sampled here were considered to support representatives of the wider marginal range-edge population (King et al., 2018a). SST were obtained from the United States' National Oceanographic and Atmospheric Administration (NOAA) daily satellite readings (http://www.seatemperature.org). 


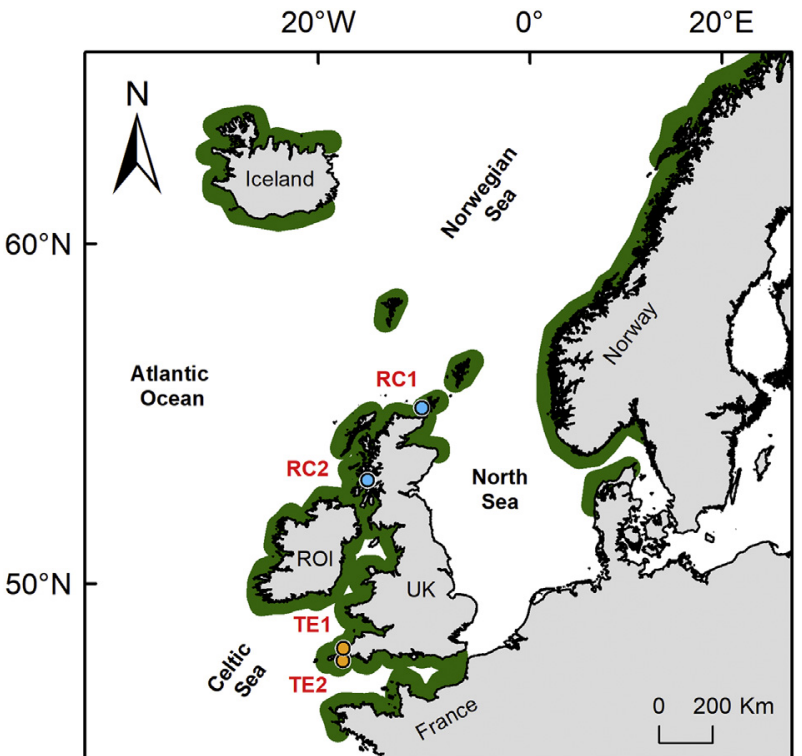

Fig. 1. Sampling sites for Laminaria digitata. Range centre $1(\mathrm{RC} 1)=$ Warbeth Bay, Orkney. Range centre $2(\mathrm{RC} 2)=$ Easdale, west-Scotland. Trailing edge 1 (TE1) = Trevone, Cornwall. Trailing edge 2 (TE2) = St Mawes, Cornwall. Shaded area $=$ approximate distribution of $L$. digitata .

\subsubsection{Sample collection and thermal assays}

To investigate the plasticity of the HSR, the experiment was conducted across two sampling periods, spring (April) and summer (September), representing thermal minima and maxima in ambient seawater temperature (Smale and Moore, unpublished). The sampling periods also varied in the intensity of recent low tide heat shock events experienced, with cooler aerial temperatures experienced over the winter and early spring compared to higher aerial temperatures and sunshine hours during the summer. Thermal assays were conducted for all sites in spring but in summer, it was only possible to conduct assays for range centre 1 and trailing edge 1 .

At each site, five mature sporophytes were collected during low spring tides from within the $L$. digitata zone. Individuals were brought back from the field in cool dark containers and held in aerated recirculating tanks for 7-14 days under photosynthetic photon flux density of $\sim 20 \mu \mathrm{mol} \mathrm{m}^{-2} \mathrm{~s}^{-1}$ (12:12 h light: dark cycle). Acclimation tanks were maintained at $8{ }^{\circ} \mathrm{C}$ in spring and $12{ }^{\circ} \mathrm{C}$ in summer, representing the lowest monthly mean temperature experienced in the field by any population for that month (i.e. range centre 1) (Smale and Moore, unpublished). This acclimation period was necessary to ensure all individuals were not physiologically stressed prior to the thermal assays.

Thermal stress assays were conducted on discs of tissue $(27 \mathrm{~mm}$ diameter, area of $11.45 \mathrm{~mm}^{2}$ ) excised from each kelp using a cork borer. Such an approach is representative of the greater organismal response and is well established in seaweed gene expression studies (e.g. Henkel and Hofmann, 2008; Pearson et al., 2009; Jueterbock et al., 2014; King et al., 2018a). Each disc was heat shocked at one of seven temperatures $\left(8,12,16,20,24,28\right.$ or $\left.32^{\circ} \mathrm{C}\right)$ for one hour in thermostatically controlled water baths with recirculating, aerated seawater. After one hour's heat shock, discs were removed, blotted dry, snap frozen in liquid $\mathrm{N}_{2}$ and stored at $-80^{\circ} \mathrm{C}$ until RNA extraction.

\subsubsection{RNA extraction and $q P C R$}

Total RNA was extracted following a protocol from Pearson et al. (2006). Primers and qPCR conditions for $h s p 70$ and two reference genes (18 s ribosomal RNA and Rubisco large sub unit, Table S1) followed that of King et al. (2018a). Relative mRNA levels were calculated as follows: Firstly, the difference in Ct values from $h s p 70$ and the internal reference gene were calculated $(\Delta \mathrm{CT})$. The $\Delta \mathrm{CT}$ value was then subtracted by the $\Delta \mathrm{CT}$ of the control $\left(8^{\circ} \mathrm{C}\right)$ from each individual ( $\Delta \Delta \mathrm{CT})$. Relative expression of $h s p 70$ was then calculated by $\mathrm{e}^{(-\Delta \Delta \mathrm{CT})}$.

\subsubsection{Defining thermal set points}

The thermal set points were defined as follows: $\mathrm{T}_{(\mathrm{on})}$; the temperature at which upregulation first becomes evident, $\mathrm{T}_{\text {peak }}$; the temperature of maximal expression and $\mathrm{T}_{\text {(off) }}$; the temperature post $\mathrm{T}_{\text {peak }}$ where there is an obvious decline in expression, indicating the HSR has been turned off.

\subsubsection{Statistical analysis}

2.2.6.1. Regional comparison. Differences in upregulation of $h s p 70$ to heat stress between regions was assessed using univariate permutational ANOVA, using the PERMANOVA module (Anderson, 2001) within Primer 6 software (Clarke and Gorley, 2001). The experiment conducted in spring was first analysed in isolation to examine site and region-level variability. Here, the model included three factors; region (fixed factor; 2 levels - range centre and trailing edge), site (random factor; 2 sites nested within each region) and temperature (fixed factor; 7 levels - 8, 12, 16, 20, 24, $28 \& 32^{\circ} \mathrm{C}$ ).

2.2.6.2. Seasonal Comparison. When comparing expression between regions and seasons only trailing edge 1 and range centre 1 were analysed. The model had three factors: region (fixed factor; 2 levels range centre and trailing edge), season (fixed factor; 2 levels - spring and autumn) and temperature (fixed factor; 5 levels - 16, 20, 24, 28 \& $32{ }^{\circ} \mathrm{C}$ ). As expression values of $h s p 70$ were normalised to ambient sea temperatures for the time of year sampled $\left(8^{\circ} \mathrm{C}\right.$ in spring and $12{ }^{\circ} \mathrm{C}$ in autumn) it was not possible to directly compare all temperatures between seasons. Instead, temperatures $16,20,24,28 \& 32{ }^{\circ} \mathrm{C}$ were used for the formal analysis between seasons.

Permutations (9999 under a reduced model) were conducted on a similarity matrix constructed from Euclidean distances between untransformed data (relative hsp70 expressions) for each sampling period. When conducting PERMANOVA analysis on univariate data using Euclidean distances, outputs (F-statistics) are analogous to traditional least-square ANOVA, without the same severity of assumptions regarding data distributions and homogeneity of variance (Anderson, 2001; McArdle and Anderson, 2001).

\subsection{Population genetics}

\subsubsection{Sample collection}

Thirty individuals, at least $5 \mathrm{~m}$ apart from one another, were haphazardly sampled at each site by excising fresh tissue from directly above the meristem between May - June 2016. Samples were then dried in individual Eppendorf's with silica drying crystals until DNA extraction.

\subsubsection{DNA extraction and microsatellite amplification}

Genomic DNA was isolated from 5 to $10 \mathrm{mg}$ of dried tissue ground to a fine powder using a ball mill. $500 \mu \mathrm{l}$ of extraction buffer $(100 \mathrm{mM}$ Tris, $25 \mathrm{mM}$ EDTA, 1.4 M NaCl, 1\% PVP and 2\% CTAB, pH 8) was added and vortexed and left at room temperature (RT) for $10 \mathrm{~min}$. RNA was digested by adding $2 \mu \mathrm{l}$ RNAse A $(10 \mathrm{mg} / \mathrm{ml})$ to the solution and incubating at $55^{\circ} \mathrm{C}$ for one hour. Total DNA was extracted by chloroform extraction, $500 \mu$ l of chloroform:Isoamyl alcohol (24:1 $v / v)$ was added, vortexed vigorously and centrifuged at $14000 \mathrm{~g}$ for $10 \mathrm{~min}$ and the upper aqueous layer transferred to a new tube. DNA was precipitated out with $30 \mu \mathrm{l}$ of ammonium acetate and $200 \mu \mathrm{l}$ isopropanol at $-20^{\circ} \mathrm{C}$ for $30 \mathrm{~min}$. Samples were centrifuged at $14000 \mathrm{~g}$ for $10 \mathrm{~min}$ at RT. Two EtoH washes were performed at $70 \%$ and $95 \%$ and recollected at $14000 \mathrm{~g}$ for $10 \mathrm{~min}$ at RT. Pellets were air dried for one hour and then resuspended in $50 \mu \mathrm{l}$ DEPC-treated water.

Twelve microsatellite markers previously developed for Laminaria digitata (Ld148, Ld158, Ld167, Ld371, Ld531 and Ld704) and Laminaria 
ochroleuca (Lo4-24, Lo454-17, Lo454-23, Lo454-24, Lo454-27, and Lo454-28) were used (Robuchon et al., 2014). Microsatellites were amplified by individual PCR in $10 \mu \mathrm{l}$ final volumes containing $1 \mathrm{X}$ GoTaq Flexi colourless reaction buffer, $2 \mathrm{mM} \mathrm{MgCl}_{2}, 150 \mu \mathrm{m}$ dNTPs, $0.35 \mathrm{U}$ GoTaq DNA polymerase (Promega) and $2 \mu \mathrm{l}$ template (1:50 dilution) following the protocol of Robuchon et al. (2014). For Ld-primers PCR cycling parameters consisted of an initial denaturation at $94^{\circ} \mathrm{C}$ for $5 \mathrm{~min}$, five cycles of touchdown PCR (denaturation at $94^{\circ} \mathrm{C}$ for $45 \mathrm{~s}$, annealing at $60{ }^{\circ} \mathrm{C}$ for $1 \mathrm{~min}$ and extension at $72{ }^{\circ} \mathrm{C}$ for $45 \mathrm{~s} ; 1{ }^{\circ} \mathrm{C}$ decrease of annealing temperature every cycle) followed 50 cycles of denaturation at $94^{\circ} \mathrm{C}$ for $45 \mathrm{~s}$, annealing at $55^{\circ} \mathrm{C}$ for $45 \mathrm{~s}$ and extension at $72{ }^{\circ} \mathrm{C}$ for $1 \mathrm{~min}$ and a final extension at $72{ }^{\circ} \mathrm{C}$ for $30 \mathrm{~min}$. For Lo-primers PCR cycling parameters consisted of an initial denaturation at $94^{\circ} \mathrm{C}$ for $5 \mathrm{~min}, 5$ cycles of denaturation at $94^{\circ} \mathrm{C}$ for $30 \mathrm{~s}$, annealing at $60^{\circ} \mathrm{C}$ for $30 \mathrm{~s}$ and extension at $72{ }^{\circ} \mathrm{C}$ for $45 \mathrm{~s}$ followed by 30 cycles where all conditions were similar apart from annealing temperature which was changed to $55^{\circ} \mathrm{C}$. A final extension of $72{ }^{\circ} \mathrm{C}$ for $20 \mathrm{~min}$ was then performed. Forward primers were fluorescently labelled with VIC (Ld167 and Lo454-17), PET (Ld148, Ld371, Lo454-23 and Lo454-28), NED (Ld158, Ld371, Lo454-23 and Lo454-28) or FAM (Ld531 and Lo454-24) dye (Eurogentec). Amplicon fragment size was analysed on an ABI PRISM 377 automated DNA sequencer (Applied Biosystems) and alleles were scored manually using PEAKSCANNER software v 1.0.

\subsubsection{Estimating genetic structure - statistical analysis}

Genetic variation within samples was characterised using number of alleles (NA), allelic richness (AR), observed heterozygosity (HO), and expected heterozygosity (HE) all calculated using FSTAT 2.9.3 (Goudet, 1995). Mean pairwise relatedness within samples was calculated using the relatedness estimator, rqg, of Queller and Goodnight (1989) in GENALEX 6.2 (Peakall and Smouse, 2006) with associated 95\% confidence intervals determined by 1000 bootstraps. Permutation of genotypes among all samples (999 times) was used to calculate the upper and lower $95 \%$ confidence intervals for the expected range of rqg under a panmictic model. Genotype frequency conformance to Hardy-Weinberg equilibrium (HWE) expectations and genotypic linkage equilibrium between pairs of loci were tested using exact tests $(10,000$ batches, 5000 iterations) in GENEPOP 3.3 (Raymond and Rousset, 1995). The hierarchical Bayesian approach implemented in BAYESCAN (Foll and Gaggiotti, 2008) was used to test for signals of selection at the loci. Genetic differentiation among samples was quantified by global and pairwise FST values, with associated significances evaluated by 10,000 permutations using FSTAT. Pairwise FST values were also calculated incorporating the null allele correction method implemented in FreeNA (Chapuis and Estoup 2006). Isolation by distance effects were tested by assessing correlation between both sets of pairwise FST values (as well as their corresponding linearised [FST / (1- FST)] (Rousset, 1997) values and the corresponding shortest sea distance between pairs of samples using Mantel tests with 10,000 permutations in GENALEX. Genetic structuring was also investigated using the Bayesian clustering method implemented in STRUCTURE 2.3.4 (Pritchard et al., 2000) to assess the most probable number of genetically distinct groups (K) represented by the data without a priori sample information. Each run had a burn-in of 100,000 Markov Chain Monte Carlo samples followed by 1,000,000 MCMC repetitions. Simulations were run 3 times for each proposed value of $\mathrm{K}$ (Aitken and Whitlock, 2013; Anderson, 2001; Angert et al., 2011; Assis et al., 2018; Assis et al., 2017) to assess convergence with optimal models inferred using $\Delta \mathrm{K}$ (Evanno et al., 2005). A PCoA of pairwise genotypic distances between individuals was performed using the methods implemented in GENELAEX 6.5 (Peakall and Smouse, 2006).
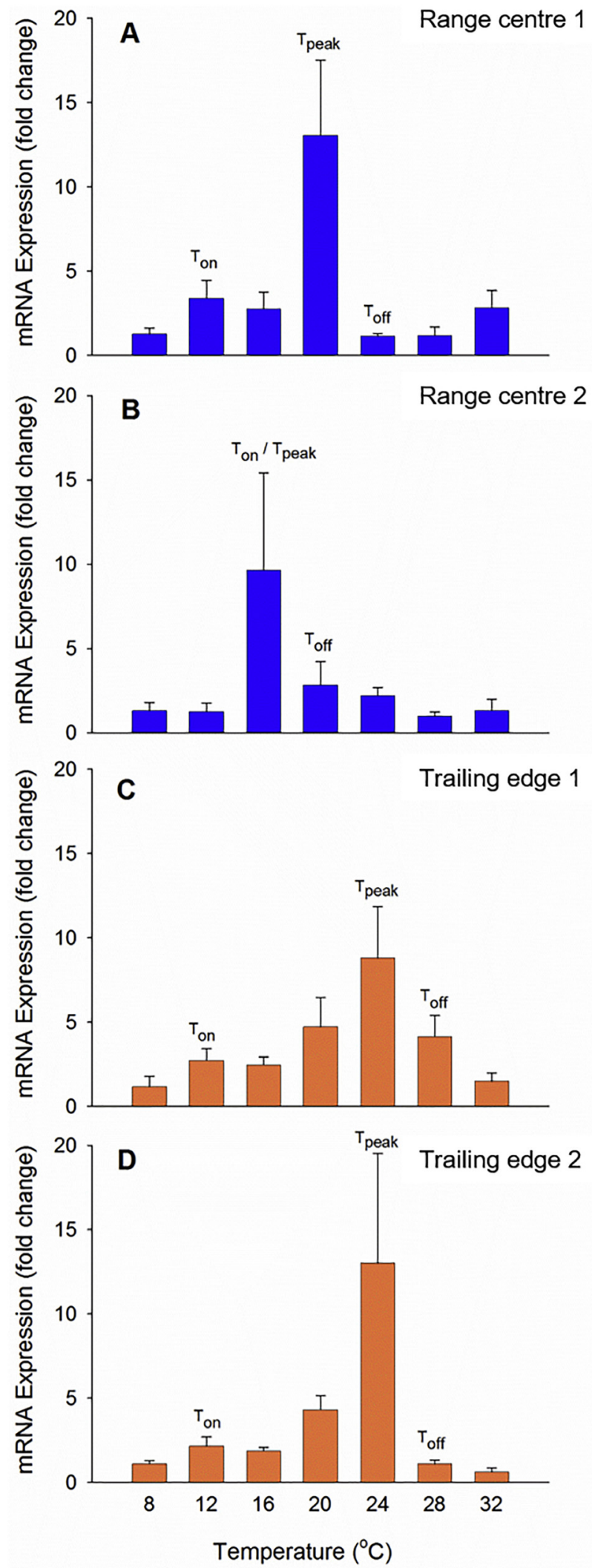

Fig. 2. Mean ( \pm 1 S.E.) relative expression of $h s p 70$ in Laminaria digitata from range centre $(A+B)$ and trailing edge locations $(C+D)$ to acute $1 \mathrm{~h}$ immersed temperature shocks in April 2015. Relative expression calculated against two housekeeping genes Rubisco and 18srRNA. $n=5$ per temperature treatment. 


\section{Results}

\subsection{Heat shock experiment}

The HSR of all experimental trials followed a clear pattern of upregulation; relative expression of $h s p 70$ increased with increasing temperature until a threshold was reached and a marked decline was subsequently observed. As such, thermal set points of the HSR ( $\mathrm{T}_{\text {on }}$, $\mathrm{T}_{\text {peak }}$ and $\mathrm{T}_{\text {off }}$ ) could readily be identified from the plotted data (Fig. 2).

\subsubsection{Regional comparison (spring sampling only)}

When all four populations were compared in spring, there was a significant interaction between region and temperature (Pseudo$\mathrm{F}_{6,12}=3.03 p=.04$; Table S2). Upregulation of $h s p 70$ occurred at higher temperatures at the trailing edge compared to range centre populations with this pattern consistent between sites within regions. Overall, magnitudes of expression were similar between populations with maximal upregulation ranging from 8.8 ( \pm 3.05 S.E) -13.06 ( \pm 4.48 S.E) compared to control values.

$\mathrm{T}_{\text {on }}$ ranged from 12 to $16^{\circ} \mathrm{C}$ with no discernible link to population origin, however, $\mathrm{T}_{\text {peak }}$ and $\mathrm{T}_{\text {off }}$ varied between regions occurring at lower temperatures in range centre populations (range centre $1 \mathrm{~T}_{\text {peak }}$ $20{ }^{\circ} \mathrm{C} \mathrm{T}_{\text {off }} 24^{\circ} \mathrm{C}$ range centre $2 \mathrm{~T}_{\text {peak }} 16^{\circ} \mathrm{C} \mathrm{T}_{\text {off }} 20^{\circ} \mathrm{C}$ ) compared to trailing edge populations (trailing edge 1 and 2 ; $\mathrm{T}_{\text {peak }} 24^{\circ} \mathrm{C} \mathrm{T}_{\text {off }} 28^{\circ} \mathrm{C}$ ) (Fig. 2).

\subsubsection{Seasonal comparison (spring and autumn sampling)}

Thermal assays were conducted in both spring and autumn for range centre 1 and trailing edge 1 to determine whether regional patterns were consistent across seasons. Here, there was no significant interaction between temperature, region and season, indicating that expression of hsp70 was similar across seasons, in both regions (Pseudo$\mathrm{F}_{4,80}=0.25, p=.92$; Table S3) (Fig. 3). However, there was a significant interaction between temperature and region (Pseudo$\mathrm{F}_{4,80}=4.7, p=.001$; Table S3), with $h s p 70$ upregulation of trailing edge 1 occurring at higher temperatures compared to range centre 1 , reinforcing the pattern observed when solely considering sampling undertaken in spring (Fig. 2).

$\mathrm{T}_{\text {peak }}$ and $\mathrm{T}_{\text {off }}$ remained fixed for both regions irrespective of sampling season (range centre $1-\mathrm{T}_{\text {peak }} 20 \& \mathrm{~T}_{\text {off }} 24^{\circ} \mathrm{C}$; trailing edge $1-\mathrm{T}_{\text {peak }}$ $24 \& \mathrm{~T}_{\text {off }} 28^{\circ} \mathrm{C}$ ) but a difference in $\mathrm{T}_{\text {on }}$ was observed. The HSR in summer was not evident until experimental temperatures were elevated to $16^{\circ} \mathrm{C}$ at range centre 1 and $24^{\circ} \mathrm{C}$ at trailing edge 1 , representing an increase in $\mathrm{T}_{(\text {on) }}$ of 4 and $12^{\circ} \mathrm{C}$ for range centre 1 and trailing edge 1 , respectively (Fig. 3).

\subsection{Population genetics}

The total number of alleles per locus range from 5 to 28 (mean $=14.3$ ). Basic summary statistics for each sample are reported in Table S4 and showed a general trend of higher variability (NA, AR, $\mathrm{HE}$ and $\mathrm{HO}$ ) among the two range centre sites compared to trailing edge sites. 18 out of 48 locus/sample tests of HWE revealed significant results, in all cases due to heterozygote deficits. With the exception of locus LD158, no locus exhibited significant heterozygote deficiencies at all four sites. Global FST was highly significant $(\mathrm{FST}=0.181$, $p<.0001$ ). All pairwise FST (Table S5) values were significant and revealed a clear hierarchical pattern wherein (i) the range centre and trailing edge populations were highly differentiated and (ii) comparisons between the two trailing edge populations yielded much higher pairwise FST values than between the two range centre populations despite the greater geographic distance between the range centre sites. This hierarchical structure was also evident from the clustering analysis for which $\Delta K$ supported $K=2$ (Fig. 4) wherein the range centre and trailing edge samples were partitioned into two distinct clusters, while at $\mathrm{K}=4$ individuals robustly assigned to distinct clusters according to
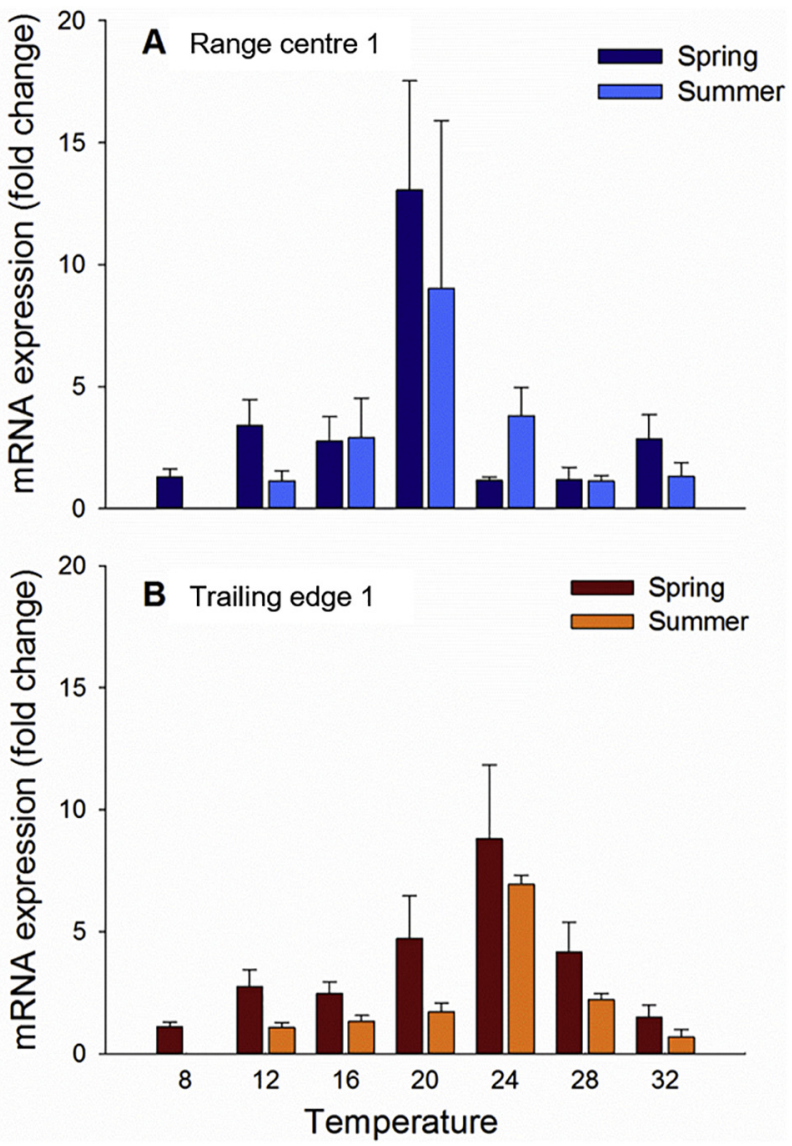

Fig. 3. Seasonal comparison of mean ( \pm 1 S.E.) relative expression of $h s p 70$ in Laminaria digitata from range centre (A) and trailing edge locations (B) to acute $1 \mathrm{~h}$ immersed temperature shocks in April and September 2015. Relative expression calculated against two housekeeping genes Rubisco and 18srRNA. $\mathrm{n}=5$ per temperature treatment.

site.

\section{Discussion}

Here, we provide three lines of evidence that taken together, suggests the presence of locally adapted thermal ecotypes, in the kelp Laminaria digitata, at trailing edge and range centre sites of its distribution. Firstly, we show clear differentiation in L. digitata's Heat Shock Response, with the thermal set points $\mathrm{T}_{\text {peak }}$ and $\mathrm{T}_{\text {off }}$ higher in trailing edge compared to range centre populations. Secondly, this pattern was mirrored across the warmest and coolest times of year, indicating that differences were fixed regardless of previous thermal history. Finally, our microsatellite data revealed little gene flow between populations, meaning dispersal is far exceeded by the selection gradient, and as such, local adaptation is likely favoured over plasticity. The existence of these ecotypes may have serious implications for our understanding of thermal safety margins and $L$. digitata's potential vulnerability to warming. Unlike many macrophyte species, L. digitata has not seen extensive population loss due to ongoing climate change but poleward range contractions are predicted over the coming century (Raybaud et al., 2013; Khan et al., 2018). As ecotypes possess a narrower thermal tolerance range than that of the overall species, thermal limits may be exceeded throughout $L$. digitata's range and not simply at its trailing edge. Moreover, L. digitata's low dispersal capacity may mean that the ability of ecotypes to track their niche in space is undermined (Assis et al., 2017) which in turn could undermine recovery (Smale and Wernberg, 2013).

The presence of local thermal ecotypes raises concerns for the 
A)

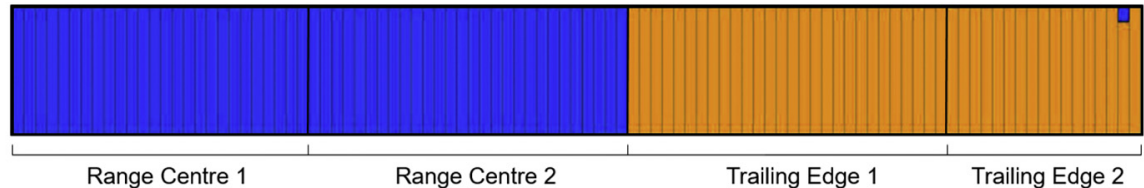

B)

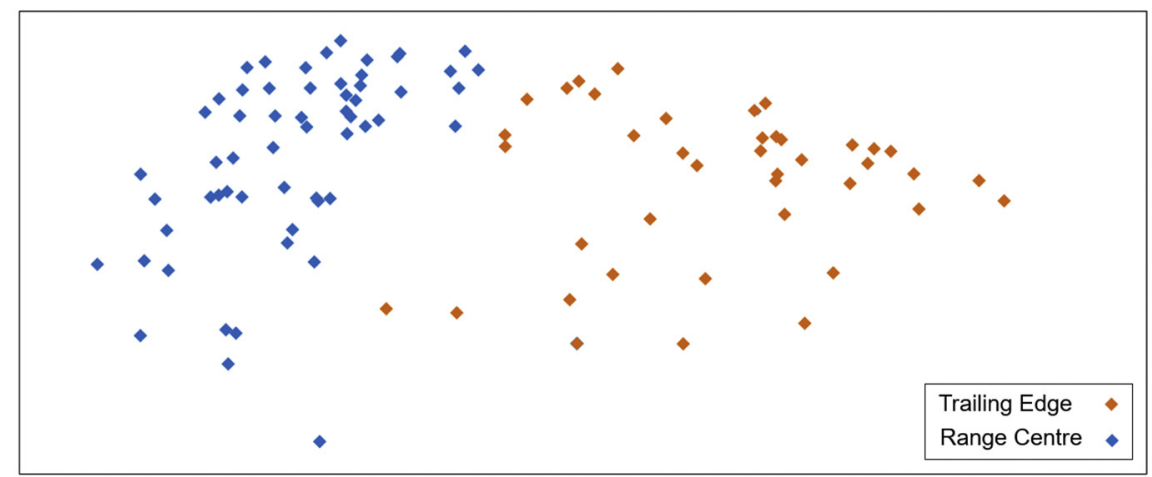

Fig. 4. A Genetic subdivision of Laminaria digitata based on STRUCTURE analysis. K1-4 were explored and $\mathrm{K}=2$ represents the most likely number of clusters based in $\Delta \mathrm{K}$ outlier identification. B Principal Coordinate analysis of pairwise genotypic distances between individuals. Individuals are coloured according to their sampling location (i.e. trailing edge or range centre). effective use of current tools to predict species responses to future warming. Environmental Niche Models (ENMs) currently represent the most utilised tool to predict future species distributions under different climate scenarios. However, they either base thermal niches on the temperatures experienced by the species as a whole or source physiological data from a single climatic location (e.g. Sunday et al., 2012). Thus, they fail to incorporate any intraspecific variation in thermal niche that could increase the complexity and predictability of species responses (Harte et al., 2004; Thomas et al., 2004; Angert et al., 2011; Hällfors et al., 2016; Peterson et al., 2018). So far, ENMs for macrophytes (e.g. Khan et al., 2018), including L. digitata (Raybaud et al., 2013; Assis et al., 2018), have taken a correlative approach, and as such, may perform poorly where local ecotypes are present (King et al., 2018a). In order to rectify this and effectively calibrate ENMs, the relationship between ecotypes and temperature (genotype-by-environment interactions) needs to be characterised. This has been successfully achieved in terrestrial forests (O'Neill et al., 2008; Pearman et al., 2010; Doney et al., 2011) but has only been possible due to the availability of comprehensive historic provenance datasets (Matyas, 1996) that are distinctly lacking in other systems.

Identification of thermal ecotypes may also have valuable applications for future management of wild and farmed kelp populations. Transplantation of warm ecotypes to cooler regions may boost local resistance to warming and allow populations to track their shifting niche. Indeed, "assisted migration" is becoming an increasingly popular concept in terrestrial forest systems with policy frameworks already being developed (McLachlan et al., 2007; Aitken and Whitlock, 2013; Williams and Dumroese, 2013). Similar approaches are also being used in commercial seaweed aquaculture in East Asia to combat recent crop failures in the kelp, Sacharina japonica (Pang et al., 2007; Liu and Pang, 2010). L. digitata is harvested from wild populations as far north as Norway and introduction of warm tolerant ecotypes further north could ensure successful harvests in the future.

Our data also provide insight into the adaptability of trailing edge populations themselves. The greater differentiation between our trailing edge sites (despite closer proximity) and lower genetic diversity could be seen as indicative of a classic trailing edge, where populations have lower effective population sizes and are more fragmented (Eckert et al., 2008). Pearson et al. (2009) found that such factors resulted in trailing edge populations of the intertidal fucoid, Fucus serratus, being less tolerant to thermal shock than central populations i.e. reduced genetic diversity resulted in maladaptation. While our trailing edge populations did exhibit reduced genetic diversity, this did not prevent the formation of thermal ecotypes. It is likely that regional biogeographic contexts can account for this. While both $F$. serratus and $L$. digitata have similar range centre and trailing edge densities (King et al. unpublished; Pearson. pers comm), they differ in their overall extent and isolation from central populations. F. serratus occupies a small geographic area at its trailing edge, which is isolated from the larger central population by a lack of suitable habitat in the Bay of Biscay. In contrast, no such geographic barriers exist for $L$. digitata and it is contiguously distributed around the rocky reefs of the western coastline of the UK. As such, differences in isolation time, population connectivity and fragmentation may underpin variability in response patterns between these two species.

One aspect of the HSR that exhibited plasticity was $\mathrm{T}_{\text {on }}$ that increased in the autumn sampling period by up to $12{ }^{\circ} \mathrm{C}$. Plasticity in $\mathrm{T}_{\text {on }}$ has been commonly documented in the literature (see Barua and Heckathorn, 2004) and is thought to allow fine tuning of the HSR to a highly variable environment, avoiding costly over production (Hochochka and Somero, 2002), which can decrease fitness (Feder et al., 1992; Krebs and Loeschcke, 1994). The cellular basis of this plasticity via the regulation of the transcription factor, heatshock factor-1 (Hsf1) which regulates expression of HSP genes (Voellmy, 1996) in what is known as the 'cellular thermometer' model (Craig and Gross, 1991). Under non-stressful conditions several HSP's bind to Hsf-1 supressing HSP transcription. When conditions become stressful, HSP's dissociate from Hsf-1 to perform their chaperoning roles (Parsell and Lindquist, 1993) and thus Hsf-1 is free to induce transcription of HSP's. Increased incubation temperature and heat shocks increase the number of gene induction events which raises the standing level of HSP's in the cell (Maloyan et al., 1999). This increased standing stock can maintain protein refolding without dissociation of HSP's from the $H s f-1$ and so induction will occur at higher temperatures. At the end of summer, when kelps may have been subjected to multiple heat shock events, standing stocks will be at their greatest and thus responsible for an increase in $\mathrm{T}_{\mathrm{on}}$.

\section{Conclusion}

Our study provides evidence for local adaptation in an important kelp, which has implications for our understanding of thermal safety margins and how this species may respond to warming. King et al. (2018b) recently found intraspecific variation in thermal tolerance and restrictive dispersal to be common traits in marine macrophytes (seaweeds and seagrasses). Therefore, local adaptation may be a common trait for kelp and seaweeds in general. Indeed, transplants that are the most direct method to detect local adaptation (Merilä and Hendry, 2014) have clearly demonstrated distinct physiological differences between native vs transplanted populations (Gerard and Du Bois, 1988; 
Saada et al., 2016). However, further experimentation on the progeny of assumed ecotypes is still required to exclude any effects from transgenerational plasticity that may mimic or obscure patterns of adaptation.

Quantifying what the presence of ecotypes means for the climate driven redistribution of $L$. digitata, and other macrophytes, is currently constrained by a lack of fine scale empirical data. The research effort required to attain the resolution needed to produce bespoke calibrated ENMs is clearly unfeasible. Therefore, a first step should be to gather the relevant data in a few ecologically representative species, such as $L$. digitata. In this way, it may be possible to make generalisations across phylogenies and allow a more precise understanding of thermal safety margins to be attained and areas of greatest vulnerability to be identified.

\section{Declaration of interest}

The authors of the study declare that there is no conflict of interest.

\section{Acknowledgments}

We thank all those who helped during field collection periods at the Scottish Association for Marine Sciences, Herriot Watt University Orkney campus and the Marine Biological Association. N.G.K. was funded by an Institute of Biological, Environmental and Rural Sciences $\mathrm{PhD}$ studentship. Funding for P.J.M. and N.G.K. was provided through a Marie Curie Career Integration Grant (PCIG10-GA- 2011- 303685) and the Aberystwyth University Research Fund (1211Z-01). L.S.H. was funded through an Aberystwyth University Doctoral Career Development Scholarship. D.A.S. is supported by an Independent Research Fellowship award by the Natural Environment Research Council of the UK (NE/K008439/1).

\section{Appendix A. Supplementary data}

Supplementary data to this article can be found online at https:// doi.org/10.1016/j.jembe.2019.03.004.

\section{References}

Aitken, S.N., Whitlock, M.C., 2013. Assisted gene flow to facilitate local adaptation to climate change. Annu. Rev. Ecol. Evol. Syst. 44, 367-388.

Anderson, M.J., 2001. A new method for non-parametric multivariate analysis of variance. Austral. Ecol. 26 (1), 32-46.

Angert, A.L., Crozier, L. G., Rissler, L.J., Gilman, S.E., Tewksbury, J.J., Chunco, A.J., 2011. Do species' traits predict recent shifts at expanding range edges? Ecol. Lett. 14 (7), 677-689.

Assis, J., Berecibar, E., Claro, B., Alberto, F., Reed, D., Raimondi, P., Serrão, E., 2017. Major shifts at the range edge of marine forests: the combined effects of climate changes and limited dispersal. Sci. Rep. 7, 44348.

Assis, J., Araújo, M., Serrão, E., 2018. Projected climate changes threaten ancient refugia of kelp forests in the North Atlantic. Glob. Change Biol. 24, e55-e66.

Barua, D., Heckathorn, S.A., 2004. Acclimation of the temperature set-points of the heatshock response. J. Therm. Biol. 29 (3), 185-193.

Bennett, S., Wernberg, T., Joy, B.A., De Bettignies, T., Campbell, A.H., 2015. Central and rear-edge populations can be equally vulnerable to warming. Nat. Commun. 6, 10280.

Brown, J.H., 1984. On the relationship between abundance and distribution of species. Am. Nat. 124 (2), 255-279.

Burrows, M.T., Schoeman, D.S., Buckley, L.B., Moore, P., Poloczanska, E.S., Brander, K.M., Brown, C., Bruno, J.F., Duarte, C.M., Halpern, B.S., Holding, J., Kappel, C.V., Kiessling, W., O'Connor, M.I., Pandolfi, J.M., Parmesan, C., Schwing, F.B., Sydeman, W.J., Richardson, A.J., 2011. The pace of shifting climate in marine and terrestrial ecosystems. Science 334 (6056), 652-655.

Chapuis, M., Estoup, A., 2006. Microsatellite null alleles and estimation of population differentiation. Mol. Biol. Evol. 24 (3), 621-631.

Clarke, K., Gorley, R., 2001. PRIMER v6: User Manual/Tutorial.PRIMER-E, Plymouth. vol. 2006.

Cosson, J., 1999. On the progressive disappearance of Laminaria digitata on the coasts of Calvados (France). Crytogam. Algol. 20, 35-42.

Craig, E.A., Gross, C.A., 1991. Is hsp70 the cellular thermometer? Trends Biochem. Sci. $16,135-140$.

Deutsch, C.A., Tewksbury, J.J., Huey, R.B., Sheldon, K.S., Ghalambor, C.K., Haak, D.C.,
Martin, P.R., 2008. Impacts of climate warming on terrestrial ectotherms across latitude. Proc. Natl. Acad. Sci. U. S. A. 105 (18), 6668-6672.

Doney, S.C., Ruckelshaus, M., Duffy, J.E., Barry, J.P., Chan, F., English, C.A., Galindo, H.M., Grebmeier, J.M., Hollowed, A.B., Knowlton, N., 2011. Climate change impacts on marine ecosystems. Annu. Rev. Mar. Sci. 4, 11-37.

Dunson, W.A., Travis, J., 1991. The role of abiotic factors in community organization. Am. Nat. 138 (5), 1067-1091.

Eckert, C., Samis, K., Lougheed, S., 2008. Genetic variation across species' geographical ranges: the central-marginal hypothesis and beyond. Mol. Ecol. 17 (5), 1170-1188.

Endler, J.A., 1977. Geographic Variation, Speciation, and Clines. Princeton University Press.

Evanno, G., Regnaut, S., Goudet, J., 2005. Detecting the number of clusters of individuals using the software STRUCTURE: a simulation study. Mol. Ecol. 14 (8), 2611-2620.

Feder, J.H., Rossi, J.M., Solomon, J., Solomon, N., Lindquist, S., 1992. The consequences of expressing hsp70 in Drosophila cells at normal temperatures. Genes Dev. 6 (8), 1402-1413.

Foll, M., Gaggiotti, O., 2008. A genome-scan method to identify selected loci appropriate for both dominant and codominant markers: a Bayesian perspective. Genetics 180 (2), 977-993.

Fraser, C.I., Morrison, A.K., McHogg, A., Macaya, E.C., van Sebille, E., Ryan, P.G. Padovan, A., Jack, C., Valdiva, N., Waters, J.M., 2018. Antarctica's ecological isolation will be broken by storm-driven dispersal and warming. Nat. Clim. Chang. 8, 704-708.

Frydman, J., 2001. Folding of newly translated proteins in vivo: the role of molecular chaperones. Annu. Rev. Biochem. 70 (1), 603-647.

García-Ramos, G., Kirkpatrick, M., 1997. Genetic models of adaptation and gene flow in peripheral populations. Evolution 51 (1), 21-28.

Gaston, K.J., 2003. The Structure and Dynamics of Geographic Ranges. Oxford University Press on Demand.

Gerard, V., Du Bois, K., 1988. Temperature ecotypes near the southern boundary of the kelp Laminaria saccharina. Mar. Biol. 97 (4), 575-580.

Gevaert, F., Janquin, M.A., Davoult, D., 2008. Biometrics in Laminaria digitata: a useful tool to assess biomass, carbon and nitrogen content. J. Sea Res. 60, 215-219.

Goudet, J., 1995. FSTAT (version 1.2): a computer program to calculate F-statistics. J. Hered. 86 (6), 485-486.

Hällfors, M.H., Liao, J., Dzurisin, J., Grundel, R., Hyvärinen, M., Towle, K., Wu, G.C., Hellmann, J.J., 2016. Addressing potential local adaptation in species distribution models: implications for conservation under climate change. Ecol. Appl. 26 (4), 1154-1169.

Harte, J., Ostling, A., Green, J.L., Kinzig, A., 2004. Biodiversity conservation: climate change and extinction risk. Nature 430 (6995).

Hartl, F.U., Hayer-Hartl, M., 2002. Molecular chaperones in the cytosol: from nascent chain to folded protein. Science 295 (5561), 1852-1858.

Hendrick, J.P., Hartl, F., 1993. Molecular chaperone functions of heat-shock proteins. Annu. Rev. Biochem. 62 (1), 349-384.

Henkel, S.K., Hofmann, G.E., 2008. Differing patterns of $h s p 70$ gene expression in invasive and native kelp species: evidence for acclimation-induced variation. J. Appl. Phycol. 20 (5), 915-924.

Hochochka, P., Somero, G.N., 2002. Biochemical Adaptation. Mechanisms and Processes in Physiological Evolution. Oxford University Press, Oxford, UK.

Hutchins, L.W., 1947. The bases for temperature zonation in geographical distribution. Ecol. Monogr. 17 (3), 325-335.

Jueterbock, A., Tyberghein, L., Verbruggen, H., Coyer, J.A., Olsen, J.L., Hoarau, G., 2013. Climate change impact on seaweed meadow distribution in the North Atlantic rocky intertidal. Ecol. Evol. 3 (5), 1356-1373.

Jueterbock, A., Kollias, S., Smolina, I., Fernandes, J.M., Coyer, J.A., Olsen, J.L., Hoarau, G., 2014. Thermal stress resistance of the brown alga Fucus serratus along the NorthAtlantic coast: acclimatization potential to climate change. Mar. Genomics 13, 27-36.

Jump, A.S., Penuelas, J., 2005. Running to stand still: adaptation and the response of plants to rapid climate change. Ecol. Lett. 8 (9), 1010-1020.

Kendrick, G.A., Walker, D.I., 1995. Dispersal of propagules of Sargassum spp. (Sargassaceae: Phaeophyta): observations of local patterns of dispersal and consequences for recruitment and population structure. J. Exp. Mar. Biol. Ecol. 192 (2), 273-288.

Khan, A.H., Levac, E., Van Guelphen, L., Pohle, G., Chmura, G.L., 2018. The effect of global climate change on the future distribution of economically important macroalgae (seaweeds) in the Northwest Atlantic. FACETS 3 (1), 275-286.

King, N.G., Wilcockson, D.C., Webster, R., Smale, D.A., Hoelters, L.S., Moore, P.J., 2018a. Cumulative stress restricts niche filling potential of habitat-forming kelps in a future climate. Funct. Ecol. 32 (2), 288-299.

King, N.G., McKeown, N.J., Smale, D.A., Moore, P.J., 2018b. The importance of phenotypic plasticity and local adaptation in driving intraspecific variability in thermal niches of marine macrophytes. Ecography. 41, 1469-1484.

Kirkpatrick, M., Barton, N.H., 1997. Evolution of a species' range. Am. Nat. 150 (1), 1-23.

Krebs, R., Loeschcke, V., 1994. Costs and benefits of activation of the heat-shock response in Drosophila melanogaster. Funct. Ecol. 730-737.

Krumhansl, K.A., Okamoto, D.K., Rassweiler, A., Novak, M., Bolton, J.J., Cavanaugh, K.C., Connell, S.D., Johnson, C.R., Konar, B., Ling, S.D., Micheli, F., Norderhaug, K.M., Perez-Matus, A., Sousa-Pinto, I., Reed, D.C., Salomon, A.K., Shears, N.T., Wernberg, T., Anderson, R.J., Barrett, N.S., Buschmann, A.H., Carr, M.H., Caselle, J.E., DerrienCourtel, S., Edgar, G.J., Edwards, M., Estes, J.A., Goodwin, C., Kenner, M.C., Kushner, D.J., Moy, F.E., Nunn, J., Steneck, R.S., Vasquez, J., Watson, J., Witman, J.D., Byrnes, J.E., 2016. Global patterns of kelp forest change over the past half-century. Proc. Natl. Acad. Sci. U. S. A. 113 (48), 13785-13790.

Leith, H., Whittaker, R.H., 1975. Primary Productivity of the Biosphere. Springer-Verlag Berlin Heidelberg. 
Liu, F., Pang, S.J., 2010. Performances of growth, photochemical efficiency, and stress tolerance of young sporophytes from seven populations of Saccharina japonica (Phaeophyta) under short-term heat stress. J. Appl. Phycol. 22 (2), 221-229.

López-Maury, L., Marguerat, S., Bähler, J., 2008. Tuning gene expression to changing environments: from rapid responses to evolutionary adaptation. Nat. Rev. Genet. 9 (8), 583.

Maloyan, A., Palmon, A., Horowitz, M., 1999. Heat acclimation increases the basal HSP72 level and alters its production dynamics during heat stress. Am. J. Physiol. Regul. Integr. Comp. Physiol. 276 (5), R1506-R1515.

Mann, K., 1973. Seaweeds: their productivity and strategy for growth. Science 182 (4116), 975-981.

Marba, N., Duarte, C.M., 2010. Mediterranean warming triggers seagrass (Posidonia oceanica) shoot mortality. Glob. Change. Biol. 16 (8), 2366-2375.

Martínez, B., Viejo, R.M., Carreno, F., Aranda, S.C., 2012. Habitat distribution models for intertidal seaweeds: responses to climatic and non-climatic drivers. J. Biogeogr. 39 (10), 1877-1890.

Matyas, C., 1996. Climatic adaptation of trees: rediscovering provenance tests. Euphytica 92 (1-2), 45-54.

McArdle, B.H., Anderson, M.J., 2001. Fitting multivariate models to community data: a comment on distance-based redundancy analysis. Ecology 82 (1), 290-297.

McLachlan, J.S., Hellmann, J.J., Schwartz, M.W., 2007. A framework for debate of assisted migration in an era of climate change. Conserv. Biol. 21 (2), 297-302.

Merilä, J., Hendry, A.P., 2014. Climate change, adaptation, and phenotypic plasticity: the problem and the evidence. Evol. Appl. 7 (1), 1-14.

Merzouk, A., Johnson, L.E., 2011. Kelp distribution in the Northwest Atlantic Ocean under a changing climate. J. Exp. Mar. Biol. Ecol. 400, 90-98.

Norton, T., 1992. Dispersal by macroalgae. Br. Phycol. J. 27 (3), 293-301.

O'Neill, G.A., Hamann, A., Wang, T., 2008. Accounting for population variation improves estimates of the impact of climate change on species' growth and distribution. J. Appl. Ecol. 45 (4), 1040-1049.

Pang, S.J., Jin, Z.H., Sun, J.Z., Gao, S.Q., 2007. Temperature tolerance of young sporophytes from two populations of Laminaria japonica revealed by chlorophyll fluorescence measurements and short-term growth and survival performances in tank culture. Aquaculture 262 (2-4), 493-503.

Parmesan, C., 2006. Ecological and evolutionary responses to recent climate change. Annu.Rev.Ecol.Evol.Syst. 37, 637-669.

Parmesan, C., Yohe, G., 2003. A globally coherent fingerprint of climate change impacts across natural systems. Nature 421 (6918), 37.

Parsell, D., Lindquist, S., 1993. The function of heat-shock proteins in stress tolerance: degradation and reactivation of damaged proteins. Annu. Rev. Genet. 27 (1), 437-496.

Peakall, R., Smouse, P.E., 2006. GENALEX 6: genetic analysis in Excel. Population genetic software for teaching and research. Mol. Ecol. Resour. 6 (1), 288-295.

Pearman, P.B., D'amen, M., Graham, C.H., Thuiller, W., Zimmermann, N.E., 2010. Withintaxon niche structure: niche conservatism, divergence and predicted effects of climate change. Ecography 33 (6), 990-1003.

Pearson, G., Lago-Leston, A., Valente, M., Serrão, E., 2006. Simple and rapid RNA extraction from freeze-dried tissue of brown algae and seagrasses. Eur. J. Phycol. 41 (1), 97-104.

Pearson, G.A., Lago-Leston, A., Mota, C., 2009. Frayed at the edges: selective pressure and adaptive response to abiotic stressors are mismatched in low diversity edge populations. J. Ecol. 97 (3), 450-462.

Pessarrodona, A., Moore, P.J., Sayer, M.D., Smale, D.A., 2018. Carbon assimilation and transfer through kelp forests in the NE Atlantic is diminished under a warmer ocean climate. Glob. Change. Biol. 24, 4386-4398 (In press).

Peterson, M.L., Doak, D.F., Morris, W.F., 2018. Both life-history plasticity and local adaptation will shape range-wide responses to climate warming in the tundra plant Silene acaulis. Glob. Change Biol. 24 (4), 1614-1625.

Poloczanska, E.S., Brown, C.J., Sydeman, W.J., Kiessling, W., Schoeman, D.S., Moore, P.J., Brander, K., Bruno, J.F., Buckley, L.B., Burrows, M.T., 2013. Global imprint of climate change on marine life. Nat. Clim. Chang. 3 (10), 919.

Pontes-da-Silva, E., Magnusson, W.E., Sinervo, B., Caetano, G.H., Miles, D.B., Colli, G.R., Diele-Viegas, L.M., Fenker, J., Santos, J.C., Werneck, F.P., 2018. Extinction risks forced by climatic change and intraspecific variation in the thermal physiology of a tropical lizard. J. Therm. Biol. 73, 50-60.

Pritchard, J.K., Stephens, M., Donnelly, P., 2000. Inference of population structure using multilocus genotype data. Genetics 155 (2), 945-959.

Queller, D.C., Goodnight, K.F., 1989. Estimating relatedness using genetic markers. Evol. 43 (2), 258-275.

Quintero, I., Wiens, J.J., 2013. Rates of projected climate change dramatically exceed past rates of climatic niche evolution among vertebrate species. Ecol. Lett. 16 (8), 1095-1103.

Raybaud, V., Beaugrand, G., Goberville, E., Delebecq, G., Destombe, C., Valero, M., Davoult, D., Morin, P., Gevaert, F., 2013. Decline in kelp in West Europe and climate.
PLoS One 8 (6), e66044.

Raymond, M., Rousset, F., 1995. An exact test for population differentiation. Evolution 49 (6), 1280-1283.

Reed, T.E., Schindler, D.E., Waples, R.S., 2011. Interacting effects of phenotypic plasticity and evolution on population persistence in a changing climate. Conserv. Biol. 25 (1), 56-63.

Robuchon, M., Le Gall, L., Mauger, S., Valero, M., 2014. Contrasting genetic diversity patterns in two sister kelp species co-distributed along the coast of Brittany, France. Mol. Ecol. 23 (11), 2669-2685.

Rousset, F., 1997. Genetic differentiation and estimation of gene flow from F-statistics under isolation by distance. Genetics 145 (4), 1219-1228.

Saada, G., Nicastro, K.R., Jacinto, R., McQuaid, C.D., Serrao, E.A., Pearson, G.A., Zardi, G.I., 2016. Taking the heat: distinct vulnerability to thermal stress of central and threatened peripheral lineages of a marine macroalga. Divers. Distrib. 22 (10), 1060-1068.

Sanford, E., Kelly, M.W., 2011. Local adaptation in marine invertebrates. Annu. Rev. Mar. Sci. 3, 509-535.

Schultze, K., Janke, K., Krüß, A., Weidemann, W., 1990. The macrofaunal and macroflora associated with Laminaria digitata and L. hyperborea at the island of Helgoland (German Bight, North Sea). Helgoländ. Meeresuntersuchungen. 44, 39-51.

Simkanin, C., Power, A.M., Myers, A., McGrath, D., Southward, A., Mieszkowska, N., Leaper, R., O'Riordan, R., 2005. Using historical data to detect temporal changes in the abundances of intertidal species on Irish shores. J. Mar. Biol. Ass. U.K 85, 1329-1340.

Smale, D.A., Moore, P.J., 2017. Variability in kelp forest structure along a latitudinal gradient in ocean temperature. J. Exp. Mar. Biol. Ecol. 486, 255-264.

Smale, D.A., Wernberg, T., 2013. Extreme climatic event drives range contraction of a habitat-forming species. Proc. Biol. Sci. 280 (1754), 20122829.

Smale, D.A., Burrows, M.T., Moore, P., O'Connor, N., Hawkins, S.J., 2013. Threats and knowledge gaps for ecosystem services provided by kelp forests: a Northeast Atlantic perspective. Ecol. Evol. 3 (11), 4016-4038.

Steneck, R.S., Graham, M.H., Bourque, B.J., Corbett, D., Erlandson, J.M., Estes, J.A., Tegner, M.J., 2002. Kelp forest ecosystems: biodiversity, stability, resilience and future. Environ. Conserv. 29 (4), 436-459.

Sunday, J.M., Bates, A.E., Dulvy, N.K., 2012. Thermal tolerance and the global redistribution of animals. Nat. Clim. Chang. 2 (9), 686.

Teagle, H., Hawkins, S.J., Moore, P.J., Smale, D.A., 2017. The role of kelp species as biogenic habitat formers in coastal marine ecosystems. J. Exp. Mar. Biol. Ecol. 492, 81-98.

Thomas, C.D., 2010. Climate, climate change and range boundaries. Divers. Distrib. 16 (3), 488-495.

Thomas, C.D., Franco, A.M., Hill, J.K., 2006. Range retractions and extinction in the face of climate warming. Trends Ecol.Evol. 21 (8), 415-416.

Thomas, C.D., Cameron, A., Green, R.E., Bakkenes, M., Beaumont, L.J., Collingham, Y.C., Erasmus, B.F., De Siqueira, M.F., Grainger, A., Hannah, L., 2004. Extinction risk from climate change. Nature 427 (6970), 145-148.

Tomanek, L., 2010. Variation in the heat shock response and its implication for predicting the effect of global climate change on species' biogeographical distribution ranges and metabolic costs. J. Exp. Biol. 213 (6), 971-979.

Tomanek, L., Somero, G.N., 1999. Evolutionary and acclimation-induced variation in the heat-shock responses of congeneric marine snails (genus Tegula) from different thermal habitats: implications for limits of thermotolerance and biogeography. J. Exp. Biol. 202 (Pt 21), 2925-2936.

Valladares, F., Matesanz, S., Guilhaumon, F., Araújo, M.B., Balaguer, L., Benito-Garzón, M., Cornwell, W., Gianoli, E., van Kleunen, M., Naya, D.E., 2014. The effects of phenotypic plasticity and local adaptation on forecasts of species range shifts under climate change. Ecol. Lett. 17 (11), 1351-1364.

Voellmy, R., 1996. Sensing stress and responding to stress. In: Feige, U., Yahara, I., Morimoto, R.I., Polla, B.S. (Eds.), Stress-inducible cellular responses. Springer, pp. 121-137.

Walther, G., Post, E., Convey, P., Menzel, A., Parmesan, C., Beebee, T.J., Fromentin, J., Hoegh-Guldberg, O., Bairlein, F., 2002. Ecological responses to recent climate change. Nature 416 (6879), 389.

Wernberg, T., Bennett, S., Babcock, R.C., de Bettignies, T., Cure, K., Depczynski, M., Dufois, F., Fromont, J., Fulton, C.J., Hovey, R.K., Harvey, E.S., Holmes, T.H., Kendrick, G.A., Radford, B., Santana-Garcon, J., Saunders, B.J., Smale, D.A., Thomsen, M.S., Tuckett, C.A., Tuya, F., Vanderklift, M.A., Wilson, S., 2016. Climatedriven regime shift of a temperate marine ecosystem. Science 353 (6295), 169-172.

Williams, M.I., Dumroese, R.K., 2013. Growing assisted migration: Synthesis of a climate change adaptation strategy. technical coordinators In: Haase, D.L., Pinto, J.R., Wilkinson, K.M. (Eds.), National Proceedings: Forest and Conservation Nursery Associations-2012.Proceedings RMRS-P-69. vol. 69. US Department of Agriculture, Forest Service, Rocky Mountain Research, Fort Collins, CO, pp. 90-96. 